\title{
KOMPARASI MEKANISME TRANSMISI KEBIJAKAN MONETER SYARIAH DAN KONVENSIONAL MELALUI JALUR HARGA ASET TERHADAP INFLASI DI INDONESIA 1)
}

\author{
Nikita Indi Kumala \\ Mahasiswa Program Studi S1 Ekonomi Islam-Fakultas Ekonomi dan Bisnis-Universitas Airlangga \\ Email: nikita.indi-12@feb.unair.ac.id \\ Suherman Rosyidi \\ Departemen Ekonomi Syariah-Fakultas Ekonomi dan Bisnis-Universitas Airlangga \\ Email: srosyidi@gmail.com
}

\begin{abstract}
:
The purpose of this study is to find out the effect of mechanism Sharia and conventional monetary policy transmission through asset prices on inflation in Indonesia during 2011-2015. The method used is quantitative analysis and the model used is OLS (Ordinary Least Square) to find out the effect in the long term and ECM Model (Error Correction Model) for short term. The data used is time series data with monthly data units during January 2011 to December 2015 period. This study uses the data from Bank Indonesia, the Central Bureau of Statistics (Badan Pusat Statistik), and the Financial Services Authority (Otoritas Jasa Keuangan). The results of this study shows that the syariah model shows significantly negative towards the inflation, and the conventional model shows not significantly towards the inflation.
\end{abstract}

\section{Keywords: Sharia monetary transmission, conventional asset prices line monetary transmission, inflation}

\section{PENDAHULUAN}

Goncangan yang terjadi pada perekonomian global dapat mempengaruhi kondisi perekonomian nasional. Untuk mengurangi dampak goncangan perekonomian global terhadap perekonomian dalam negeri, dibutuhkan kebijakan yang efektif dan efisien, baik kebijakan moneter maupun kebijakan fiskal serta kebijakan-kebijakan ekonomi lainnya. Fokus penerapan kebijakan moneter di Indonesia sesuai UU No. 23 tahun 1999 yang telah diubah menjadi UU No. 3 tahun 2004 mengenai kebijakan moneter menyebutkan bahwa Bank Indonesia diberi amanah sebagai otoritas moneter ganda yang dapat menjalankan kebijakan moneter konvensional maupun syariah. Dengan amanah tersebut, kebijakan moneter 1) Jurnal ini merupakan bagian dari skripsi Nikita Indi Kumala NIM: 041211433044, yang diuji pada tanggal 30 Januari 2017

yang ditempuh memiliki dua wajah atau dual monetary policy, yakni konvensional dan syariah (Yusuf, 2011).

Kebijakan moneter suatu bank sentral atau otoritas moneter dimaksudkan untuk mempengaruhi kegiatan ekonomi riil dan harga melalui mekanisme transmisi yang terjadi. "Mekanisme transmisi kebijakan moneter dapat bekerja melalui berbagai saluran, seperti suku bunga, agregat moneter, kredit, nilai tukar, harga aset, dan ekspektasi" (Warjiyo dan Agung, 2002). Kebijakan moneter digunakan oleh pemerintah sebagai pengendali inflasi, yaitu kebijakan stabilisasi harga. Oleh karena itu dibutuhkan adanya mekanisme transmisi kebijakan moneter beserta instrumen-instrumen yang digunakan. Terbentuknya sistem moneter syariah di Indonesia saat ini diharapkan menjadi 
Kumala, et al/Jurnal Ekonomi Syariah Teori dan Terapan Vol. 4 No. 10 Oktober 2017: 817-832; KOMPARASI MEKANISME TRANSMISI KEBIJAKAN MONETER SYARIAH DAN KONVENSIONAL MELALUI JALUR HARGA ASET TERHADAP INFLASI DI INDONESIA

solusi dari kegagalan yang diakibatkan oleh sistem moneter konvensional yang terpaku pada sistem bunga. Sistem bunga membawa kegiatan perekonomian dalam tindak spekulasi yang akan menghambat perekonomian sektor riil untuk berkembang dan akhirnya pertumbuhan ekonomi tidak berdiri dengan kuat atau rapuh meskipun angka pertumbuhan ekonomi tinggi. Asumsinya adalah dengan adanya kebijakan moneter syariah, kebijakan moneter khususnya di Indonesia akan terbebas dari sistem bunga (riba) dan diharapkan dapat mencapai tujuan moneter yang lebih baik. Seperti yang diterangkan dalam AlQur'an, surat Al-Baqarah ayat 276 dibawah ini:

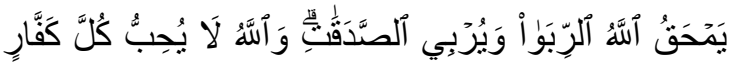
rVY أَثْبِ

Yamĥaqullāhur-ribā wa yurbīş-Şadaqāti Wallāhu Lā Yuhibbu Kulla Kaffārin 'Asīim

"Allah memusnahkan riba dan menyuburkan sedekah. Dan Allah tidak menyukai setiap orang yang tetap dalam kekafiran, dan selalu berbuat dosa."

Bukti dalam penelitian teoritisnya, penelitian terdahulu yang dilakukam Yoghi pada tahun 2011 membandingkan bagaimana efektivitas kebijakan moneter konvensional dan syariah, dan terbukti bahwa berdasarkan hasil estimasi VECM diketahui bahwa dalam jangka panjang, instrumen syariah merupakan instrumen yang tepat dalam mengendalikan tingkat inflasi. Penelitian mekanisme transmisi kebijakan moneter memberikan penjelasan mengenai bagaimana perubahan (shock) instrumen kebijakan moneter dapat mempengaruhi variabel makroekonomi lainnya hingga terwujudnya sasaran akhir kebijakan moneter. Seberapa besar pengaruhnya terhadap harga dan kegiatan di sektor riil, semuanya sangat tergantung pada perilaku atau respon perbankan dan dunia usaha lainnya terhadap shock yang terjadi pada instrumen kebijakan moneter yaitu suku bunga Sertifikat Bank Indonesia (SBI) (Deswita, 2013: 159).

Penelitian ini mengkhususkan dengan menggunakan mekanisme transmisi moneter jalur harga aset. Penelitian dengan menggunakan jalur harga aset masih sedikit sekali dilakukan. Meski demikian, terdapat studi mengenai bekerjanya transmisi moneter melalui saluran harga aset seperti yang dilakukan oleh Idris pada tahun 2002. Penelitian Idris tersebut menyatakan bahwa harga aset tanah dan properti sebetulnya merupakan indikator yang lebih baik untuk mengkaji saluran harga aset tersebut, namun terbentur masalah data maka digunakanlah harga saham dalam studinya. Keterbatasan data tersebut maka penelitian ini menggunakan variabel obligasi dan sukuk sebagai indikator harga aset (Nashruddin, 2012).

Sedikitnya penelitian mengenai mekanisme transmisi kebijakan moneter dengan melihat jalur harga aset, serta adanya kebijakan sistem moneter ganda (konvensional dan syariah) yang disahkan oleh UU yang salah satu tujuannya adalah untuk mengendalikan stabilitas harga (inflasi), manakah sistem moneter yang 
Kumala, et al/Jurnal Ekonomi Syariah Teori dan Terapan Vol. 4 No. 10 Oktober 2017: 817-832; KOMPARASI MEKANISME TRANSMISI KEBIJAKAN MONETER SYARIAH DAN KONVENSIONAL MELALUI JALUR HARGA ASET TERHADAP INFLASI DI INDONESIA

masih lebih efektif digunakan dalam mengendalikan inflasi. Maka, dari penjelasan di atas, peneliti tertarik melakukan penelitian komparasi mekanisme transmisi kebijakan moneter syariah dan konvensional melalui jalur harga aset terhadap inflasi di Indonesia.

\section{LANDASAN TEORI}

Kebijakan moneter adalah upaya mengendalikan atau mengarahkan perekonomian makro ke kondisi yang diinginkan (yang lebih baik) dengan mengatur jumlah uang beredar. Yang dimaksud dengan kondisi yang lebih baik adalah meningkatnya output keseimbangan dan atau terpeliharanya stabilitas harga (inflasi terkontrol) melalui kebijakan moneter. Pemerintah dapat mempertahankan, menambah atau mengurangi jumlah vang beredar dalam upaya mempertahankan kemampuan ekonomi bertumbuh, sekaligus mengendalikan inflasi (Rahardja dan Manurung, 2002: 435). Pada penelitian ini menggunakan inflasi sebagai tolak ukur keberhasilan dari mekanisme kebijakan moneter melalui jalur harga aset. Sejajar dengan kebijakan moneter, kebijakan moneter syariah adalah usaha dalam mengendalikan keadaan ekonomi makro agar dapat berjalan sesuai dengan yang diinginkan melalui pengaturan jumlah vang beredar dalam perekonomian. Bank sentral Islam harus bertanggung jawab untuk mengeluarkan vang dengan koordinasi dengan pemerintah, mengusahakan stabilitas internal dan eksternalnya (Chapra, 2000: 102).

Mekanisme transmisi kebijakan moneter merupakan proses yang kompleks, oleh karena itu dalam teori ekonomi moneter sering disebut dengan "black box". Hal ini terutama karena transmisi dipengaruhi oleh tiga faktor, yaitu (i) perubahan perilaku bank sentral, bank, dan para pelaku ekonomi dalam berbagai aktivitas ekonomi dan keuangannya, (ii) lamanya tenggat waktu (time lag) dari saat ditempuhnya kebijakan ekonomi sampai sasaran inflasi tercapai, serta (iii) terjadinya perubahan pada saluran-saluran transmisi kebijakan moneter itu sendiri sesuai dengan perkembangan ekonomi dan keuangan di negara yang bersangkutan (Warjiyo, 2004: 4). Berikut ini merupakan saluran transmisi kebijakan moneter di Indonesia:

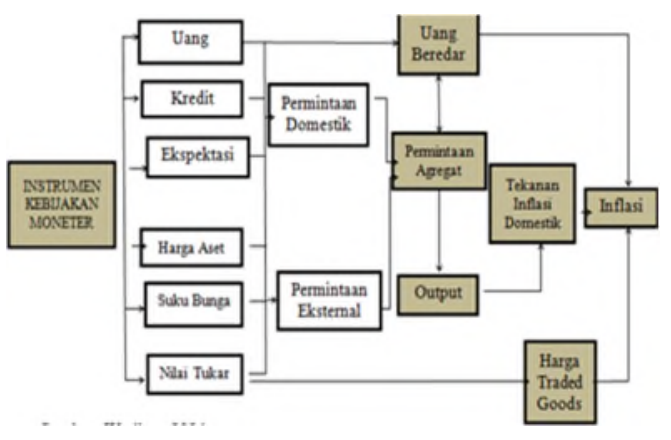

\section{Saluran- saluran transmisi kebijakan moneter di Indonesia}

\section{Saluran Harga Aset}

Mekanisme transmisi melalui jalur harga aset menekankan bahwa kebijakan moneter berpengaruh pada perubahan harga aset dan kekayaan masyarakat, yang kemudian akan berpengaruh 
Kumala, et al/Jurnal Ekonomi Syariah Teori dan Terapan Vol. 4 No. 10 Oktober 2017: 817-832; KOMPARASI MEKANISME TRANSMISI KEBIJAKAN MONETER SYARIAH DAN KONVENSIONAL MELALUI JALUR HARGA ASET TERHADAP INFLASI DI INDONESIA

terhadap konsumsi dan investasi. Apabila pelaku kebijakan moneter, yaitu bank sentral, melakukan kebijakan moneter kontraktif, maka hal tersebut akan mendorong peningkatan suku bunga dan pada saatnya akan menekan harga aset perusahaan. Penurunan harga aset dapat berakibat pada dua hal, yaitu mengurangi kemampuan perusahaan untuk melakukan ekspansi, dan mengurangi nilai kekayaan yang pada saatnya akan mengurangi pengeluaran untuk konsumsi. Secara keseluruhan, kedua hal tersebut berdampak pada penurunan pengeluaran agregat. Kekayaan mempunyai dampak terhadap konsumsi, Pracoyo (2005: 57) menyebutkan ada 4 faktor penting yang menentukan perilaku konsumsi rumah tangga, yaitu: pendapatan, kekayaan, tingkat suku bunga dan harapan di masa yang akan datang.

Menurut Rahardja dan Manurung (2002: 435-437) ada tiga instrumen utama yang digunakan dalam kebijakan moneter, yaitu: (i)Operasi Pasar Terbuka (Open Market Operation); (ii)Fasilitas Diskonto (Discount Rate); (iii)Rasio Cadangan Wajib (Reserve Requirement Ratio); (iii)Imbauan Moral (Moral Persuassion).

Sedangkan instrumen kebijakan moneter syariah Menurut Chapra (2000: 141-151), yang dapat mencapai sasaran sosioekonomi masyarakat Islam seperti: (i)Operasi Pasar Terbuka; (ii)Moral Persuassion; (iii)Lending Ratio; (iv)Profit
Sharing Ratio; (v)Cadangan Wajib Minimum (Reserve Requirement).

Inflasi menjadi salah satu indikator makro ekonomi yang penting dalam perekonomian Indonesia. Tingkat inflasi sangat mempengaruhi aktifitas pelaku ekonomi baik itu di sektor rill maupun disektor moneter. Tingkat inflasi adalah keadaan yang mengindikasikan semakin melemahnya daya beli yang diikuti dengan semakin merosotnya nilai rill mata vang suatu negara (Khalwaty, 2000: 5). Sukirno (2004: 333) menyatakan bahwa inflasi adalah kenaikan harga barang dan jasa, yang terjadi karena permintaan bertambah lebih besar dibandingkan dengan penawaran barang di pasar. Dengan kata lain, banyak orang yang memburu barang yang terlalu sedikit. Menurut Sukirno (2004: 333), berdasarkan pada sumber atau penyebab kenaikan harga-harga yang berlaku, tingkat inflasi biasanya dibedakan kepada tiga bentuk, yaitu: (i)Inflasi tarikan permintaan; (ii) Inflasi desakan biaya; (iii) Inflasi diimpor.

Secara umum, inflasi memiliki dampak positif dan dampak negatif tergantung arah tingkat inflasi. Apabila tingkat inflasi itu ringan, justru mempunyai pengaruh yang positif dalam arti dapat mendorong perekonomian lebih baik, yaitu meningkatkan pendapatan nasional dan membuat orang bergairah untuk bekerja, menabung dan melakukan investasi. Sebaliknya, dalam masa tingkat inflasi yang parah, yaitu pada saat terjadi tingkat inflasi tak terkendali, yang tinggi sehingga keadaan perekonomian 
Kumala, et al/Jurnal Ekonomi Syariah Teori dan Terapan Vol. 4 No. 10 Oktober 2017: 817-832; KOMPARASI MEKANISME TRANSMISI KEBIJAKAN MONETER SYARIAH DAN KONVENSIONAL MELALUI JALUR HARGA ASET TERHADAP INFLASI DI INDONESIA

menjadi kacau dan perekonomian dirasakan lesu, orang menjadi tidak bersemangat kerja, menabung atau melakukan investasi dan produksi karena harga meningkat dengan cepat (Pohan, 2008)

\section{Hubungan Antar Variabel}

\section{Pengaruh Obligasi Terhadap Inflasi}

Hasil guncangan kebijakan moneter dalam fluktuasi harga aset dengan kebijakan moneter pelonggaran dapat meningkatkan harga saham, serta penanaman dana pada obligasi, saham atau sekuritas lainnya. Sementara itu, di sektor ekonomi riil, kebijakan moneter selanjutnya mempengaruhi pertumbuhan ekonomi, investasi, ekspor dan impor, hingga terwujud dalam pertumbuhan ekonomi dan inflasi yang merupakan sasaran akhir kebijakan moneter (Warjiyo, 2004)

\section{Pengaruh Sukuk Terhadap Inflasi}

Ketika pertumbuhan ekonomi meningkat, maka penerbitan sukuk juga mengalami peningkatan karena kondisi makroekonomi domestik dalam keadaan baik. begitu juga sebaliknya.

Jumlah uang beredar berlebihan pun akan mengakibatkan inflasi, dan ketika terjadi peningkatan jumlah vang beredardi masyarakat, pemerintah akan menerbitkan sukuk sebagai salah satu instrumen dalam OPT ( Fatah, 2011)

\section{Pengaruh SBI dan SBIS Terhadap Inflasi}

Untuk menjalankan transmisi tersebut diperlukan adanya sarana bagi berlangsungnya sistem moneter, yang dalam penelitian ini adalah instrumen operasi pasar terbuka (OPT), salah satunya SBI untuk yang konvensional dan SBIS untuk syariahnya. Dengan adanya penjualan surat-surat berharga ini maka tabungan giral masyarakat dan cadangan yang dimilki oleh bank umum akan berkurang, yang berarti jumlah vang beredar juga akan berkurang. Ketika jumlah uang beredar berkurang, maka inflasi pun akan ikut berkurang atau menurun (Warjiyo, 2004)

\section{Pengaruh JUB Terhadap Inflasi}

Hubungan anatar inflasi dan JUB didasari oleh teori kuantitas vang MV = PT. Jika mengacu pada teori diatas, maka penyebab maka utama dari satu-satunya yang memungkinkan inflasi muncul adalah terjadinya kelebihan vang sebagai akibat penambahan jumlah vang beredar di masyarakat. Jika bank Sentral ingin mencapai dan memelihara tingkat inflasi yang rendah dan stabil, maka yang harus dilakukan adalah mengendalikan atau mengontrol jumlah uang beredar (http://ekonomi.kabo.biz)

\section{METODE PENELITIAN}

Penelitian ini termasuk dalam kelompok penelitian kuantitatif yaitu penelitian yang analisisnya ditujukan untuk menguji hipotesis, pengukuran data dan membuat generalisasi.

\section{Operasional}

Identifikasi Variabel dan Definisi

1. Sertifikat Bank Indonesia (SBI)

SBI adalah surat berharga yang dikeluarkan oleh Bank Indonesia sebagai pengakuan utang berjangka waktu 
Kumala, et al/Jurnal Ekonomi Syariah Teori dan Terapan Vol. 4 No. 10 Oktober 2017: 817-832; KOMPARASI MEKANISME TRANSMISI KEBIJAKAN MONETER SYARIAH DAN KONVENSIONAL MELALUI JALUR HARGA ASET TERHADAP INFLASI DI INDONESIA

pendek (1-3 bulan) dengan sistem diskonto atau bunga (Bank Indonesia, 2015)

2. Sertifikat Bank Indonesia Syariah (SBIS)

SBIS adalah sertifikat yang diterbitkan Bank Indonesia sebagai bukti penitipan dana jangka pendek (1-3 bulan). SBIS merupakan piranti moneter yang sesuai dengan prinsip pada Bank Syariah yang diciptakan dalam rangka pelaksanaan pengendalian moneter dan dapat dimanfaatkan oleh Bank Syariah untuk mengatasi bila terjadi kelebihan pada tingkat likuiditas (Bank Indonesia, 2015)

3. Obligasi (Bonds)

Obligasi merupakan surat utang jangka menengah-panjang yang dapat di pindahtangankan yang berisi janji dari pihak yang menerbitkan untuk membayar imbalan berupa bunga pada periode tertentu dan melunasi pokok utang pada waktu yang telah ditentukan kepada pihak pembeli obligasi tersebut (Bank Indonesia, 2015)

4. Sukuk (Islamic Bonds)

Menurut peraturan BAPEPAM dan LK Nomor IX.A.13 definisi sukuk adalah "efek syariah berupa sertifikat atau bukti kepemilikan yang bernilai sama dan mewakili bagian yang tidak tertentu."

5. Jumlah Uang Beredar $\left(M_{2}\right)$

Uang beredar dalam arti luas sering disebut juga sebagai likuiditas perekonomian dengan diberi simbol $\mathrm{M}_{2}$ yang didefiniskan sebagai seluruh alat pembayaran yang terdiri dari uang kartal
(C), uang giral (D), dan uang kuasi (T) (Solikin, 2005)

6. Inflasi $(\triangle I H K)$

IHK digunakan sebagai proksi mengukur tingkat inflasi (Bank Indonesia, 2015)

\section{Jenis dan Sumber Data}

Jenis data yang digunakan dalam penelitian ini yaitu data sekunder time series, dimulai dari bulan Januari 2011 hingga Desember 2015. Sumber data berasal dari instansi Bank Indonesia, Otoritas Jasa Keuangan, dan Badan Pusat Statistik.

\section{Prosedur Pengumpulan Data}

Penelitian ini adalah penelitian statistik deskriptif dan menggunakan data sekunder, maka metode yang digunakan dalam mengumpulkan data adalah sebagai berikut:

\section{Field Research}

Data yang digunakan dalam penelitian ini adalah data yang bersifat sekunder, yaitu adalah data yang diperoleh melalui hasil pengolahan pihak kedua (data eksternal) atau data yang sudah dipublikasi untuk menjelaskan gejala dari suatu fenomena yang ada, seperti pusat referensi pada $\mathrm{BI}, \mathrm{BEl}$ ataupun OJK (Anshori dan Iswati, 2009).

\section{Library Research}

Data yang digunakan dalam penelitian ini adalah data yang diperoleh dari membaca literatur, buku, artikel, jurnal dan sejenisnya yang berhubungan dengan aspek yang diteliti sebagai upaya untuk 
Kumala, et al/Jurnal Ekonomi Syariah Teori dan Terapan Vol. 4 No. 10 Oktober 2017: 817-832; KOMPARASI MEKANISME TRANSMISI KEBIJAKAN MONETER SYARIAH DAN KONVENSIONAL MELALUI JALUR HARGA ASET TERHADAP INFLASI DI INDONESIA

memperoleh data yang valid. Termasuk dalam kategori ini adalah data dan keterangan yang diperoleh dari internet (Anshori dan Iswati, 2009).

\section{Model Analisis dan Hipotesis}

Model analisis yang digunakan dalam penelitian dibagi menjadi dua model, yaitu mekanisme transmisi kebijakan moneter syariah dan mekanisme transmisi kebijakan moneter konvensional. Model pertama, yaitu mekanisme transmisi kebijakan moneter konvensional melalu jalur harga aset terhadap inflasi, dan model kedua, yaitu mekanisme transmisi moneter syariah melalui jalur harga aset terhadap inflasi. Kedua model tersebut terlihat pada tabel di bawah ini.

\section{Model Analisis Penelitian Mekanisme Transmisi Kebijakan Moneter Melalui Jalur Harga Aset}

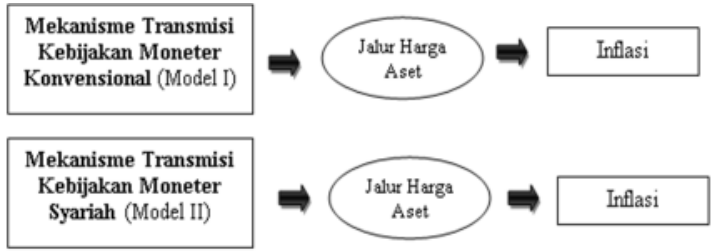

Sumber: Penulis

\section{Hipotesis}

$\mathrm{H}_{1}$ : Diduga terdapat hubungan mekanisme transmisi moneter konvensional melalui jalur harga aset dalam mempengaruhi inflasi di Indonesia.

$\mathrm{H}_{2}$ : Diduga terdapat hubungan mekanisme transmisi moneter syariah melalui jalur harga aset dalam mempengaruhi inflasi di Indonesia.

$\mathrm{H}_{3}$ : Diduga mekanisme transmisi moneter syariah lebih berpengaruh daripada transmisi moneter konvensional melalui jalur harga aset dalam mempengaruhi inflasi di Indonesia.

\section{Teknik Analisis Data}

Dalam penelitian ini dilakukan dua analisis, yaitu analisis keseimbangan jangka panjang dengan menggunakan uji kointegrasi (cointegration test) dan analisis jangka pendek dengan metode regresi linier ECM (Error Correction Model). Sebelum melakukan analisis harus dilakukan uji terhadap kestasioneran data. Konsep yang banyak dipakai untuk menguji kestasioneran pada data time series adalah uji akar unit (unit root test) atau dikenal juga dengan Uji Augmented Dickey-Fuller (ADF). Pengujian akar unit untuk semua variabel yang digunakan dalam analisis time series perlu dilakukan untuk memenuhi kesahihan analisis ECM (Error Correction Model). Ini berarti bahwa data yang digunakan harus bersifat stasioner, atau dengan kata lain perilaku data yang stasioner memiliki varian yang tidak terlalu besar dan mempunyai kecenderungan untuk mendekati nilai rata-ratanya.

Error Correction Model (ECM) atau yang dikenal dengan model koreksi kesalahan adalah suatu model yang digunakan untuk melihat pengaruh jangka panjang dan jangka pendek dari masingmasing variabel bebas terhadap variabel terikat (Satria, 2004). ECM diterapkan dalam analisis ekonometrika untuk data time series karena kemampuan yang dimiliki ECM dalam meliput banyak variabel untuk menganalisis fenomena 
Kumala, et al/Jurnal Ekonomi Syariah Teori dan Terapan Vol. 4 No. 10 Oktober 2017: 817-832; KOMPARASI MEKANISME TRANSMISI KEBIJAKAN MONETER SYARIAH DAN KONVENSIONAL MELALUI JALUR HARGA ASET TERHADAP INFLASI DI INDONESIA

ekonomi jangka panjang dan mengkaji konsistensi model empiris dengan teori ekonometrika, serta dalam usaha mencari pemecahan terhadap persoalan variabel time series yang tidak stasioner dan regresi yang lancung (spurious) dalam analisis ekonometrika (http://a-research.upi.edu). Dalam menentukan model regresi linier melalui pendekatan ECM, yaitu dengan uji stasioneritas data dan uji derajat integrasi, uji kointegrasi dan pengujian residual semua variabel, dan yang terakhir estimasi ECM dalam jangka pendek dan jangka panjang.

IV. HASIL DAN PEMBAHASAN

1. Hasil Uji Stasioneritas Data (Unit Root Test) dan Derajat Integrasi

Hasil Uji Unit Root Tingkat Level

\begin{tabular}{cccc}
\hline Variabel & $\begin{array}{c}\text { ADF test } \\
\text { statistic }\end{array}$ & prob. & $\begin{array}{c}\text { Mc } \\
\text { Kinnon } \\
\text { Critical } \\
\text { Values }\end{array}$ \\
\cline { 2 - 2 } & Intercept & & $5 \%$ \\
SBI & -1.358783 & $0.8626 \wedge$ & -3.489228 \\
SBIS & -1.941684 & $0.6183 \wedge$ & -3.500495 \\
\hline SKK & -2.300541 & $0.4270 \wedge$ & -3.487845 \\
\hline OBL & -2.498663 & $0.3278 \wedge$ & -3.487845 \\
JUB & -2.242679 & $0.4577 \wedge$ & -3.487845 \\
INF & -2.359423 & $0.3963 \wedge$ & -3.489228 \\
\hline
\end{tabular}

Keterangan: $\wedge$, tidak stasioner pada $\alpha=$ $5 \%$,.

Dari hasil uji stasioner untuk keenam variabel yang ditampilkan dalam tabel 4.1 dapat disimpulkan bahwa tidak ada variabel yang stasioner pada tingkatan (derajat) level [l(0)] dengan cara membandingkan probabilitas dari masingmasing variabel dengan $\alpha=5 \%$, Hal ini terlihat dari lebih besarnya nilai probabilitas masing-masing variabel yaitu
0.8626 untuk SBI, 0.6183 untuk SBIS, 0.4270 untuk SKK, 0.3278 untuk OBL, 0.4577 untuk JUB dan untuk INF 0.3963 terhadap $\alpha=5 \%$.

\begin{tabular}{|c|c|c|c|}
\hline Variabel & $\begin{array}{l}\text { ADF test } \\
\text { Statistic }\end{array}$ & prob. & $\begin{array}{c}c \text { Mc } \\
\text { Kinnon } \\
\text { Critical } \\
\text { Values }\end{array}$ \\
\hline & Intercept & & $5 \%$ \\
\hline DSBI & -6.310548 & $0.0000^{*}$ & -3.489228 \\
\hline DSBIS & -11.50796 & $0.0000^{*}$ & -3.489228 \\
\hline DSKK & -7.014800 & $0.0000^{*}$ & -3.489228 \\
\hline DOBL & -9.468687 & $0.0000^{*}$ & -3.489228 \\
\hline DJUB & -7.323540 & $0.0000^{*}$ & -3.490662 \\
\hline DINF & -4.985454 & $0.0008^{*}$ & -3.489228 \\
\hline
\end{tabular}

Keterangan: ${ }^{*}$, stasioner pada $\alpha=5 \%$,

Karena masing-masing variabel tidak stasioner di tingkat level, maka perlu dilakukan uji derajat integrasi pada tingkat first difference. Hasil pengujian stasioneritas variabel pada tabel 4.2 menunjukkan bahwa semua variabel yang terdiri dari DSBI, DSBIS, DSKK, DOBL, DJUB, DINF stasioner pada pada tingkat $\alpha=5 \%$.

\section{Uji Kointegrasi dan Pengujian Residual}

\section{Model I (Konvensional)}

Hasil persamaan uji kointegrasi pada model I,

$Y=C+S B I_{\dagger}+O B_{+}+J U B_{\dagger}+$ et

$I N F=-86.76672+2.225782 S B I_{\dagger}+$

$1.6805300 \mathrm{BL}_{\dagger}+3.055936 \mathrm{JUB}+$

dengan tabel hasil uji kointegrasi sebagai berikut: 
Kumala, et al/Jurnal Ekonomi Syariah Teori dan Terapan Vol. 4 No. 10 Oktober 2017: 817-832; KOMPARASI MEKANISME TRANSMISI KEBIJAKAN MONETER SYARIAH DAN KONVENSIONAL MELALUI JALUR HARGA ASET TERHADAP INFLASI DI INDONESIA

Hasil Uji Regresi OLS Pada Model I (Konvensional)

\begin{tabular}{ccc}
\hline \multicolumn{3}{c}{ (Konvensional) } \\
\hline Variabel & Koefisien & Prob. \\
$\mathrm{SBI}$ & 2.225782 & $0.0151^{*}$ \\
$\mathrm{OBL}$ & 1.680530 & 0.7392 \\
$\mathrm{JUB}$ & 3.055936 & 0.5614 \\
$\mathrm{C}$ & -86.76672 & 0.0009 \\
\multicolumn{2}{c}{ R-squared } & 0.230457 \\
\multicolumn{2}{c}{ Adj $R$-squared } & 0.189231 \\
\hline
\end{tabular}

Keterangan: *, stasioner pada $\alpha=5 \%$,

Dari tabel diatas, diketahui bahwa variabel SBI mempunyai pengaruh signifikan positif terhadap inflasi karena nilai probabilitas tidak lebih dari $5 \%$. Setelah melakukan estimasi OLS, tahapan yang dilakukan selanjutnya adalah untuk mencari residualnya. Residual yang stasioner di tingkat level I(0), menunjukkan adanya hubungan jangka panjang di antara semua variabelnya.

\begin{tabular}{cccc}
\multicolumn{3}{c}{ Hasil Uji Unit Root Residu Tingkat Level } \\
\hline Variabel & $\begin{array}{c}\text { ADF test } \\
\text { Statistic }\end{array}$ & prob. & $\begin{array}{c}\text { Mc } \\
\text { Kinnon } \\
\end{array}$ \\
& & & $\begin{array}{c}\text { Critical } \\
\text { Values }\end{array}$ \\
\cline { 2 - 2 } & & & $5 \%$ \\
RESID02 & -5.473199 & $0.0002 *$ & -3.490662 \\
\hline
\end{tabular}

Keterangan: ${ }^{*}$, stasioner pada $\alpha=5 \%$,

Dari tabel 4.4 yang telah signifikan, didapatkan pesamaan jangka panjang dengan cara meregresikan INFLASI sebagai dependent variable dan $\mathrm{SBI}, \mathrm{OBL}$, JUB dan RESID02 sebagai independent variable. RESID02 di sini dianggap sebagai et (error term) dalam estimasi ECM.

\section{Model II (Syariah)}

Hasil persamaan uji kointegrasi pada model II,

$Y=C+S B I S_{\dagger}+S K K_{\dagger}+J U B_{\dagger}+$ et
$\mathrm{INF}=59.00076+0.361167 \mathrm{SB} / \mathrm{S}_{\dagger}+$

$11.84550 S K_{\dagger}-11.04053 J_{U} \cup B_{t}$,

dengan tabel hasil uji kointegrasi sebagai

berikut:

Hasil Uji Regresi OLS Pada Model II (Syariah)

\begin{tabular}{ccc}
\hline \multicolumn{3}{c}{ Dependent Variabel : INF } \\
\hline Variabel & Koefisien & Prob. \\
SBIS & 0.361167 & 0.6008 \\
SKK & 11.84550 & $0.0006^{*}$ \\
JUB & -11.04053 & $0.0078^{*}$ \\
C & 59.00076 & 0.0546 \\
\multicolumn{2}{c}{ R-squared } & 0.288758
\end{tabular}

Adj R-squared 0.250656

Keterangan: ${ }^{*}$, stasioner pada $\alpha=5 \%$,

Dari hasil tabel 4.5 diketahui bahwa variabel SKK dan JUB mempunyai pengaruh signifikan positif terhadap inflasi karena nilai probabilitas tidak lebih dari 5\%. Residual yang stasioner di tingkat level I(0), menunjukkan adanya hubungan jangka panjang di antara semua variabelnya.

\section{Hasil Uji Unit Root Residu Tingkat Level}

\begin{tabular}{|c|c|c|c|}
\hline $\begin{array}{c}\text { Variabe } \\
\text { । }\end{array}$ & $\begin{array}{l}\text { ADF test } \\
\text { statistic }\end{array}$ & prob. & $\begin{array}{c}\text { Mc } \\
\text { Kinnon } \\
\text { Critical } \\
\text { Values }\end{array}$ \\
\hline & Intercept & & $5 \%$ \\
\hline RESID01 & $\begin{array}{c}- \\
5.659828\end{array}$ & $0.0001 *$ & $\begin{array}{c}- \\
3.489228\end{array}$ \\
\hline
\end{tabular}

Keterangan: *, stasioner pada $\alpha=5 \%$,

Dari tabel 4.6 yang telah signifikan, didapatkan persamaan jangka panjang dengan cara meregresikan INF sebagai dependent variable dan SBIS, SKK, JUB dan RESIDOI sebagai independent variable. RESIDOI di sini dianggap sebagai et (error term) dalam estimasi ECM.

\section{Estimasi ECM (Error Correction Model)}


Kumala, et al/Jurnal Ekonomi Syariah Teori dan Terapan Vol. 4 No. 10 Oktober 2017: 817-832; KOMPARASI MEKANISME TRANSMISI KEBIJAKAN MONETER SYARIAH DAN KONVENSIONAL MELALUI JALUR HARGA ASET TERHADAP INFLASI DI INDONESIA

Model I (Konvensional)

Hasil Uji ECM Jangka Panjang Model I

\begin{tabular}{ccc}
\hline \multicolumn{3}{c}{ Dependent Variable : INF } \\
\hline Variabel & Koefisien & Prob. \\
SBI & 2.225782 & $0.0151^{*}$ \\
OBL & 1.680530 & 0.7392 \\
JUB & 3.055936 & 0.5614 \\
RESID02 & -0.872189 & $0.0000^{*}$ \\
C & -86.76672 & 0.0009 \\
\multicolumn{2}{c}{ R-squared } & 0.230457 \\
Prob (F-statistic) & 0.001999 \\
\hline
\end{tabular}

Keterangan: ${ }^{*}$, stasioner pada $\alpha=5 \%$,

Persamaan ECM jangka panjang yang didapat adalah:

$Y_{\dagger}=C+\beta_{1} X_{1 \dagger}+\beta_{2} X_{2 \dagger}+\beta_{3} X_{3 \dagger}+$ et

$I N F=-86.76672+2.225782 S B I_{\dagger}+$

$1.680530 O \mathrm{BL}_{\dagger}+3.055936 \mathrm{JUB}_{\dagger}+$

(1)et

Dari persamaan dan tabel diatas dapat diketahui bahwa dalam jangka panjang, SBI berpengaruh terhadap perubahan inflasi (Y). Nilai probabilitas variabel $\mathrm{SBI}$ sebesar $0.0151=1,51 \%$ yang artinya dibawah ambang batas $5 \%$. Hal ini menunjukan bahwa dalam jangka panjang dalam cateris paribus, kondisi variabel $\mathrm{SBI}$ berpengaruh signifikan terhadap inflasi (Y). Nilai koefisien variabel SBI sebesar 2.225782 yang artinya peningkatan SBI sebesar 1 unit dapat menyebabkan penurunan inflasi (Y) sebesar 2.225782 unit. Pengaruh yang diestimasikan membawa ke tingkat equilibriumnya ini mempunyai nilai pengaruh yang positif pada saat variabelvariabel ini sama-sama berada pada tahun ke ( $\mathrm{t})$. Hasil estimasi dari persamaan jangka panjang menunjukan nilai $R^{2}$ sebesar 0.230457, yang artinya dalam jangka panjang, SBI mempunyai pengaruh 23.0457\% terhadap inflasi. Dilihat dari nilai Prob (F-statistic) yang bernilai 0.001999, menunjukan bahwa semua variabel bebas dalam jangka panjang secara signifikan dan simultan berpengaruh terhadap variabel terikat (inflasi) karena tingkat signifikansi kurang dari $5 \%$ sehingga $\mathrm{H}_{0}$ ditolak.

Berikut dibawah ini akan menampilkan hasil uji ECM jangka pendek untuk model I.

Hasil Uji ECM Jangka Pendek Model I

Dependent Variabel : D(INF)

\begin{tabular}{ccc}
\hline Variabel & Koefisien & Prob. \\
\hline $\mathrm{D}(\mathrm{SBI})$ & 0.521497 & 0.5791 \\
$\mathrm{D}(\mathrm{OBL})$ & 3.277141 & 0.4563 \\
$\mathrm{D}(\mathrm{JUB})$ & 6.537171 & 0.3998 \\
RESID02 & -0.143911 & $0.0515^{*}$ \\
$\mathrm{C}$ & -0.157763 & 0.2808 \\
\multicolumn{2}{c}{ R-squared } & 0.102721 \\
\hline \multicolumn{2}{c}{ Prob (F-Statistic) } & 0.202203 \\
\hline
\end{tabular}

Keterangan: *, stasioner pada $\alpha=5 \%$,

Persamaan ECM nya adalah:

$Y=C+a_{1} X_{1 \dagger}+a_{2} X_{2 \dagger}+\ldots . .+\mu_{\dagger-1}$

$\mathrm{INF}=-0.157763+0.521497 S B I_{\dagger}+$

$3.2771410 \mathrm{BL}_{\dagger}+6.537171 J U \mathrm{~B}_{\dagger}-0.143911 \mu_{\dagger-1}$

Syarat sah nya ECM adalah nilai $\mu_{t-1}$ (RESID02) harus negatif. Nilai dari $\mu_{t-1}$ (RESID02) digunakan untuk mengintrepretasikan seberapa cepat equilibrium akan kembali ke posisi semula.

Tabel 4.6 diatas menunjukan variabel dari model I yaitu SBI, OBL, dan JUB tidak ada yang mampu mempengaruhi inflasi dalam jangka pendek dikarenakan nilai a melebihi 
Kumala, et al/Jurnal Ekonomi Syariah Teori dan Terapan Vol. 4 No. 10 Oktober 2017: 817-832; KOMPARASI MEKANISME TRANSMISI KEBIJAKAN MONETER SYARIAH DAN KONVENSIONAL MELALUI JALUR HARGA ASET TERHADAP INFLASI DI INDONESIA

ambang batas 0.05 , lalu nilai koefisien $\mu_{t-1}$ sebesar -0157763 yang artinya bahwa model ECM dalam penelitian ini dapat digunakan karena koefisien negarif. Nilai koefisien $\mu_{t-1}$ (RESID02) sebesar -0.157763 menunjukan bahwa kecepatan penyesuaian (speed of adjustment) inflasi menuju ke kondisi keseimbangan adalah sebesar 15,7763\%. Hasil estimasi dari persamaan jangka panjang menunjukan nilai $R^{2}$ sebesar 0.102721 , yang artinya bahwa $10.2721 \%$ model inflasi (Y) dapat dijelaskan oleh variabel independennya yaitu, SBI, OBL dan JUB, sedangkan sisanya sebesar $89.7279 \%$ dijelaskan oleh variabel lain di luar persamaan. Dilihat dari Prob (Fstatistic) yang bernilai 0.202203, semua variabel bebas dalam jangka pendek secara simultan dan signifikan tidak mempunyai pengaruh terhadap variabel terikat (inflasi) karena tingkat signifikansi lebih dari 5\% sehingga $\mathrm{H}_{0}$ diterima.

\section{Model II (Syariah)}

\section{Hasil Uji ECM Jangka Panjang Model II}

\begin{tabular}{ccc}
\hline \multicolumn{3}{c}{ Dependent Variabel : INF } \\
\hline Variabel & Koefisien & Prob. \\
SBIS & 0.361167 & 0.6008 \\
SKK & 11.84550 & $0.0006^{*}$ \\
JUB & -11.04053 & $0.0078^{*}$ \\
RESID01 & -0.753680 & $0.0000^{*}$ \\
C & 59.00076 & 0.0546 \\
\multicolumn{2}{c}{ R-squared } & 0.288758 \\
\hline \multicolumn{2}{c}{ Prob (F-statistic) } & 0.000243 \\
\hline
\end{tabular}

Keterangan: *, menunjukkan variabel stasioner pada $\alpha=5 \%$

Persamaan ECM jangka panjang yang didapat adalah:

$Y_{t}=C+\beta_{1} X_{1 \dagger}+\beta_{2} X_{2 t}+\beta_{3} X_{3 t}+$ et
INF $=59.00076+0.361167 \mathrm{SBIS}_{+}+$

$11.84550 \mathrm{SKK}_{\dagger}-11.04053 \mathrm{JUB}_{\dagger}+$

(1)et

Dari persamaan dan tabel diatas diatas dapat diketahui bahwa dalam jangka panjang, variabel SKK dan JUB berpengaruh terhadap perubahan inflasi (Y). Nilai probabilitas variabel SKK sebesar 0.0006 dan variabel JUB dengan nilai probabilitas sebesar 0.0078 yang artinya berada di dalam ambang batas 0.05 . Hal ini menunjukan bahwa dalam jangka panjang, variabel SKK dan JUB berpengaruh signifikan terhadap inflasi $(Y)$. Nilai koefisien variabel SKK sebesar 11.84550 yang artinya menurut anggapan ceteris paribus peningkatan SKK sebesar 1 unit dapat menyebabkan penurunan inflasi (Y) sebesar 11.84550 unit dan nilai koefisien JUB sebesar -11.04053 yang artinya peningkatan JUB sebesar 1 unit dapat menyebabkan penurunan inflasi ( $Y$ ) sebesar 11.0405 unit. Pengaruh yang diestimasikan membawa ke tingkat equilibriumnya ini mempunyai nilai pengaruh yang positif pada saat variabelvariabel ini sama-sama berada pada tahun ke (†). Hasil estimasi dari persamaan jangka panjang menunjukan nilai $R^{2}$ sebesar 0.288758, yang artinya dalam jangka panjang, SKK dan JUB mempunyai pengaruh $28.8758 \%$ terhadap inflasi. Sementara itu Prob (F-statistic) yang bernilai 0.000243, menunjukan bahwa semua variabel bebas dalam jangka panjang secara signifikan dan simultan berpengaruh terhadap variabel terikat 
Kumala, et al/Jurnal Ekonomi Syariah Teori dan Terapan Vol. 4 No. 10 Oktober 2017: 817-832; KOMPARASI MEKANISME TRANSMISI KEBIJAKAN MONETER SYARIAH DAN KONVENSIONAL MELALUI JALUR HARGA ASET TERHADAP INFLASI DI INDONESIA

(inflasi) karena tingkat signifikansi kurang dari $5 \%$ sehingga $\mathrm{H}_{0}$ ditolak.

\section{Hasil Uji ECM Jangka Pendek Model II}

Dependent Variabel : D(INF)

\begin{tabular}{ccc}
\hline Variabel & Koefisien & Prob. \\
D(SBIS) & -0.075518 & 0.8652 \\
D(SKK) & 0.634829 & 0.8551 \\
D(JUB) & 5.870788 & 0.4749 \\
RESIDO1 & -0.247781 & $0.0048^{*}$ \\
C & -0.100329 & 0.4552 \\
R-squared & 0.164169 \\
Prob (F-Statistic) & 0.046188 \\
\hline
\end{tabular}

Keterangan: *, menunjukkan variabel stasioner pada $\alpha=5 \%$

Persamaan ECM nya adalah :

$Y=C+a_{1} X_{1 \dagger}+a_{2} X_{2 \dagger}+\ldots . .+\mu_{\dagger-1}$

INF $=-0.100329-0.075518 S B I S_{+}+$

$0.634829 S K_{\dagger}+5.870788 J U B_{\dagger}-2.477821 \mu_{\dagger-1}$

Syarat sah nya ECM adalah nilai $\mu_{t-1}$ (RESID01) harus negatif. Nilai dari $\mu_{t-1}$ (RESID01) digunakan untuk mengintrepretasikan seberapa cepat equilibrium akan kembali ke posisi semula.

Pada tabel 4.7 diatas menunjukan variabel dari model I yaitu SBI, OBL, dan JUB tidak ada yang mampu mempengaruhi inflasi dalam jangka pendek dikarenakan nilai probabilitas melebihi ambang batas 0.05. Variabel tambahan yaitu RESID01 menunjukan nilai probabilitas signifikan sebesar $0.0048<0.05$ sedangkan nilai koefisien $\mu_{t-1}$ sebesar 0.247781 yang artinya bahwa model ECM dalam penelitian ini dapat digunakan. Nilai koefisien $\mu_{t-1}$ (RESID01) sebesar 0.247781 menunjukan bahwa kecepatan penyesuaian (speed of adjustment) inflasi menuju ke kondisi keseimbangan adalah sebesar -0.247781\%. Hasil estimasi dari persamaan jangka panjang menunjukan nilai $R^{2}$ sebesar 0.164169, yang artinya bahwa $16.4169 \%$ model inflasi (Y) dapat dijelaskan oleh variabel independennya yaitu, SBIS, sukUk dan JUB, sedangkan sisanya sebesar $83.5831 \%$ dijelaskan oleh variabel lain diluar persamaan. Dilihat dari nilai Prob (F-statistic) yang bernilai 0.046188, menunjukan bahwa semua variabel dalam jangka pendek bebas secara simultan dan signifikan tidak mempunyai pengaruh terhadap variabel terikat karena tingkat signifikansi lebih dari $5 \%$ sehingga $\mathrm{Ho}_{0}$ diterima.

\section{Pembahasan}

Berdasarkan hasil estimasi dari penelitian ini pada periode tahun 2011 hingga 2015, diketahui bahwa dalam jangka panjang variabel dari model II (syariah) yaitu SKK (sukUk) dan JUB mempunyai pengaruh yang kuat dan signifikan terhadap inflasi. Sedangkan variabel dari model I (konvensional) yaitu hanya SBI saja yang berpengaruh signifikan terhadap inflasi. Hal ini dapat terlihat pada probabilitas seluruh variabel yang signifikan dalam jangka panjang terdapat pada kisaran kurang dari $\alpha=5 \%$,. Sedangkan dalam jangka pendek, variabel model | maupun model || pun tidak ada yang berpengaruh signifikan terhadap inflasi. Hal ini dapat terlihat juga pada probabilitas seluruh variabel yang tidak signifikan dalam jangka pendek terdapat pada kisaran lebih dari $\alpha=5 \%$,

Sesuai dengan teori yang telah dikemukakan pada BAB 2, SBI dan SBIS dapat berpengaruh signifikan terhadap inflasi. Dengan adanya penjualan surat- 
Kumala, et al/Jurnal Ekonomi Syariah Teori dan Terapan Vol. 4 No. 10 Oktober 2017: 817-832; KOMPARASI MEKANISME TRANSMISI KEBIJAKAN MONETER SYARIAH DAN KONVENSIONAL MELALUI JALUR HARGA ASET TERHADAP INFLASI DI INDONESIA

surat berharga ini maka tabungan giral masyarakat dan cadangan yang dimiliki oleh bank umum kan berkurang, yang artinya jumlah vang beredar juga akan berkurang. Ketika jumlah vang beredar berkurang, maka inflasi pun akan ikut berkurang. Mendukung dari teori tersebut, hasil estimasi jangka panjang, menunjukan bahwa variabel SBI dari model I (konvensional) mempunyai dampak yang signifikan terhadap inflasi di Indonesia pada periode tahun 2011-2015. Terlihat dari probabilitas SBI sebesar 0.0151 yang berarti stasioner terhadap $a=5 \%$ dengan nilai $R^{2}$ pada estimasi jangka panjang pada variabel model I sebesar 0.230457 yang berarti dapat menerangkan variabel dependennya (inflasi) hanya sebesar 23.0457\%. Tetapi dalam jangka pendek, tidak ditemukan variabel dari model I dan Il yang mampu secara signifikan mempengaruhi inflasi.

Teori yang diemukakan pada BAB 2 sebelumnya pun dituliskan bahwa, jumlah vang beredar dapat mempengaruhi harga aset (sukuk dan obligasi), dimana aktivitas tersebut akan mempengaruhi konsumsi dan investasi di masyarakat dan pada akhirnya akan mempengaruhi stabilitas harga (inflasi). Mendukung dari teori tersebut juga bahwa berdasarkan hasil estimasi ECM pada jangka panjang ada dua variabel dari model II (syariah) yaitu SKK (sUkUk) dan JUB yang secara signifikan dapat mempengaruhi inflasi. Terlihat dari besarnya nilai probabilitas SKK sebesar 0.0006 dan JUB sebesar 0.0078 keduanya sama-sama stasioner terhadap $a=5 \%$, Dengan nilai $R^{2}$ pada estimasi jangka panjang pada variabel model II sebesar 0.288758 yang berarti dapat menerangkan variabel dependennya (inflasi) sebesar $28.8758 \%$ lebih besar daripada model I yang hanya $23.0457 \%$ saja.

Penelitian harga aset memang dinyatakan sebagai indikator yang baik untuk mengkaji pengaruh terhadap inflasi dalam jangka panjangnya, seperti sukuk dan obligasi yang digunakan penelitian ini sebagai indikator harga aset. Dilihat dari hasil estimasi jangka panjang dan pendek, secara statistik obligasi tidak mampu mempengaruhi inflasi, dikarena probabilitas lebih dari $5 \%$, sesuai dengan teori pada $B A B 1$ dan $B A B 2$ bahwa variabel obligasi sebagai indikator harga aset pada transmisi kebijakan moneter konvensional, dimana sistem perekonomian moneter konvensional mengandumg unsur riba (bunga) yang akan membawa perilaku ekonomi dalam tindak spekulasi. Sedangkan dilihat dari hasil estimasi jangka panjang dan pendek, secara statistik sukuk mampu mempengaruhi inflasi secara signifikan dalam jangka panjang meskipun secara statistik pula bahwa sukuk tidak mampu mempengaruhi inflasi secara signifikan dalam jangka pendek. Sesuai pada BAB 2 bahwa dampak sukuk terhadap inflasi menurut teori transmisi makroekonomi bahwa penerbitan sukuk sebagai instrumen saham dan investasi dari transmisi kebijakan moneter syariah bisa dimanfaatkan oleh pemerintah untuk 
Kumala, et al/Jurnal Ekonomi Syariah Teori dan Terapan Vol. 4 No. 10 Oktober 2017: 817-832; KOMPARASI MEKANISME TRANSMISI KEBIJAKAN MONETER SYARIAH DAN KONVENSIONAL MELALUI JALUR HARGA ASET TERHADAP INFLASI DI INDONESIA

mengatasi masalah makroekonomi, yaitu salah satunya inflasi. Terbukti dalam hasil estimasi ECM dalam penelitian ini bahwa sukUk dan JUB secara statistik signifikan dalam jangka panjang dapat mempengaruhi inflasi di Indonesia.

\section{SIMPULAN}

Berdasarkan dari hasil dan pembahasan yang sudah di jelaskan, maka simpulan yang dapat diambil dari skripsi ini adalah sebagai berikut.

1. Berdasarkan hasil estimasi dari penelitian ini pada periode Januari 2011 hingga Desember 2015 diketahui bahwa pada model I (konvensional) variabel SBI dalam jangka panjang mempunyai pengaruh signifikan terhadap inflasi dan dengan $R^{2}$ sebesar 0.230457 yaitu berarti dapat menerangkan variabel inflasi (dependen) hanya sebesar $23.0457 \%$. Demikian dengan hasil estimasi jangka panjang pada variabel model II (syariah), ada dua variabel yang signifikan terhadap inflasi, yaitu SKK (sUkUk) dan JUB. Dengan nilai $R^{2} 0.288758$ yang artinya dapat menerangkan variabel inflasi (dependen) sebesar $28.8758 \%$ yaitu lebih besar $5.8301 \%$ dari hasil $R^{2}$ model । (konvensional).

2. Dilihat dari hasil estimasi jangka pendek bahwa variabel keduanya (model I dan II) menurut statistik secara signifikan tidak ada yang mampu mempengaruhi inflasi dalam jangka pendek. Dikarenakan variabel dari kedua model tersebut tidak ada yang signifikan pada $\alpha=5 \%$,. Tetapi variabel residu dari kedua model tersebut menampilkan hasil negatif yang artinya model analisis ECM dapat diterapkan dalam penelitian ini.

3. Dari hasil estimasi jangka pendek dan jangka panjang yang diujikan pada kedua model I dan II (konvensional dan syariah) dapat disimpulkan bahwa hasil estimasi variabel pada model II yang lebih berpengaruh dalam mengatasi inflasi. Dikarenakan ada dua variabel yang dalam jangka panjang yang signifikan yaitu SKK dan JUB, dimana sesuai dengan teori bahwa diterbitkannya sukuk sebagai instrumen saham dan investasi bisa dimanfaatkan oleh pemerintah untuk mengurangi masalah makroekonomi, salah satunya inflasi. Dengan diterbitkannya sukuk, dimana aktivitas tersebut akan mempengaruhi konsumsi dan investasi di masyarakat dan akan mempengaruhi stabilitas harga (inflasi). Demikian JUB sebagai vang beredar di masyarakat (JUB/M2) yang dikeluarkan oleh BI berfungsi sebagai otoritas moneter untuk mengendalikan stabilitas harga (inflasi), dan hal ini sesuai dengan teori yang dikemukakan oleh beberapa ilmuwan bahwa kebijakan moneter yang dimaksud adalah upaya pengendalian atau mengarahkan perekonomian makro ke kondisi yang diinginkan (yang lebih baik) dengan mengatur jumlah uang beredar. yang dapat disimpulkan bahwa kebijakan moneter syariah yang tanpa riba (bunga) itu lebih mampu mengatasi masalah perekonomian di Indonesia. 
Kumala, et al/Jurnal Ekonomi Syariah Teori dan Terapan Vol. 4 No. 10 Oktober 2017: 817-832; KOMPARASI MEKANISME TRANSMISI KEBIJAKAN MONETER SYARIAH DAN KONVENSIONAL MELALUI JALUR HARGA ASET TERHADAP INFLASI DI INDONESIA

DAFTAR PUSTAKA

Abdul Fatah, Dede. 2011. Perkembangan Obligasi Syariah (Sukuk) di Indonesia: Analisis Peluang dan Tantangan. Fakultas Agama Islam Universitas Azzahra. Jakarta

Anshori, Muslich dan Sri Iswati. 2009. Buku Ajar Metodologi Penelitian Kuantitatif. Fakultas Ekonomi Universitas Airlangga. AUP. Surabaya

BAPEPAM-LK Nomor IX.A.13

Chapra, Umer. 2000. Sistem Moneter Islam. Jakarta: Gema Insani Press

Citra, Yogi Pratama. Effectiveness of Conventional and Syariah Monetary Policy Transmission. Economic Sciences and Development Study, Islamic State University Syarif Hidayatullah. Tazkia Islamic Finance and Business Review. Volume 8.1. Jakarta

Herlina, Deswita. 2013. Identifikasi Mekanisme Transmisi Kebijakan Moneter di Indonesia Tahun 20002011. Universitas Sultan Ageng Tirtayasa, Serang.

Kementerian Agama RI. 2014. Al-Qur'an dan Terjemahan untuk Wanita. Penerbit WALI: Oasis Terrace Recident. Jakarta

Khalwaty, Tajul, 2000. Inflasi dan Solusinya. PT. Gramedia Pustaka Utama, Jakarta

Mishkin, F.S. 1995. Symposium on the Monetary Transmission
Mechanism. $5^{\text {th }}$ ed. New york : addison Wesley Longman Inc

Nashruddin, Ahmad. 2012. Peran Pasar Modal Syariah Dalam Transmisi Kebijakan Moneter Indonesia (Studi Kasus Jakarta Islamic Index). Sekolah Tinggi Ekonomi Islam (STEI) Tazkia. Bogor

Pohan, Aulia. 2008. Kerangka Kebijakan Moneter dan Implementasinya di Indonesia. PT. RajaGrafindo Persada: Jakarta

2008. Potret Kebijakan Moneter di Indonesia. PT. RajaGrafindo Persada: Jakarta

Pracoyo, A. 2005. Aspek Dasar Ekonomi Mikro. PT. Gramedia Widiasarana Indonesia. Jakarta

Rahardja, Prathama dan Manurung, Mandala. 2001. Teori Ekonomi Makro. Penerbit Fakultas Ekonomi Universitas Indonesia.

Solikin dan Suseno. 2005. Uang: Pengertian,

Penciptaan, Peranannya dalam Perekonomian. Jakarta: Bank Indonesia

Sukirno, Sadono, 1981, Pengantar Teori Makro Ekonomi, Jakarta; Bina Grafika.

Warjiyo, Perry. 2004. Mekanisme Transmisi Kebijakan Moneter di Indonesia Seri Kebanksentralan No.11. PPSK Bank Indonesia. Jakarta

Warjiyo, Perry dan J. Agung. 2002. Transmission Mechanism of 
Kumala, et al/Jurnal Ekonomi Syariah Teori dan Terapan Vol. 4 No. 10 Oktober 2017: 817-832; KOMPARASI MEKANISME TRANSMISI KEBIJAKAN MONETER SYARIAH DAN KONVENSIONAL MELALUI JALUR HARGA ASET TERHADAP INFLASI DI INDONESIA

Monetary Policy. Bank Indonesia.

Jakarta

Yusuf, Mohammad. Analisis Efektivitas

Jalur-Jalur Transmisi Kebijakan

Moneter dengan Sasaran Tunggal

Inflasi di Indonesia. Fakultas

Ekonomi dan Bisnis Universitas

Brawijaya. Malang

http://s41f.

blogspot.co.id/2010/01/instrumen-

moneter-islam

(diakses 7 Oktober 2016)

http://ekonomi.kabo.biz/201 1/01/jumlah-

vang-beredar-m2.htmle $\mathrm{m}=1$

(diakses 14 Agustus 2016)

http://a-research.upi.edu (diakses 27

Desember 2016)

http://statistikceria.blogspot.co.id (diakses

27 Desember 2016)

http://dsnmui.or.id (diakses 6 September 2016)

http://bi.go.id (diakses 9 Agustus 2016)

http://ojk.go.id (diakses 9 Agustus 2016)

shttp://bps.go.id (diakses 9 Agustus 2016) 